SINAI Journal of Applied Sciences

\title{
A PRELIMINARY STUDY ON THE REPRODUCTION OF THE RABITFISH, SIGANUS RIVULATUS (Forsskal, 1775) IN BARDAWIL LAGOON, NORTH SINAI, EGYPT
}

\author{
Sammah A. M, Hassanen, G. D.I and M. S. Ahmed \\ Dept. of Fisheries Resources and Aquaculture, Faculty of Environ. Agri. Sc., EL-Arish, Suez \\ Canal University, Egypt.
}

\begin{abstract}
From April to December, 2012, a total of 583 specimens (rabitfish, Siganus rivulatus) were collected at random from the mixed catch of the Bardawil lagoon. Monthly, total length, total weight, and the weighing of gonads were recorded. The specimens were sexed with naked eye. By monthly variation of the Gonadosomatic index values, the higher values were recorded in June, July and August with a peak in June where spawning season. The sex ratio was $1: 1$ around the year with slightly change of ratio month by month between females to males. The length at first maturity was estimated at $13.8 \mathrm{~cm}$ and $14.4 \mathrm{~cm}$ for female and male respectively. The absolute fecundity was calculated as fish of $14.4 \mathrm{~cm}(41.5 \mathrm{~g}$.) to lay eggs about 57244 reaching maximum of about 356410 eggs for a fish of $21.6 \mathrm{~cm}(149 \mathrm{~g}$.). The relative fecundity gradually increased from 1228 to 2392 eggs per gm with average of $1798 \mathrm{~g}^{-}$ 1. Prevent fishing craft Shrimp (Al kalssa) in the months of June to July, where spawning season of $S$. rivulatus in the Bardawil lagoon.
\end{abstract}

Key Words: Bardawil lagoon, Siganus rivulatus, Reproduction.

\section{INTROUDACTION}

Rabbitfish, Siganus rivulatus is untargeted species by fishermen in the Bardawil lagoon but it is common fish and demanded by consumers. Rabbitfish is considered among the most successful invaders in the Mediterranean Sea (Golani et al. 2002, 2004 and Galil, 2007). Knowledge of the sex ratio and the state of maturity of individuals in a population and also estimation of fecundity are very important in studies of productivity and population dynamic (Cailliet et al., 1996 and Bariche et al., 2009). The size at sexual maturity of fish may be important to assess the optimum size of first capture of a species. Gonadosomatic index (GSI) is often used to follow the reproductive cycle of a species over the year at monthly.

This index, which assumes that a gonad increases in size with increasing development, compares the mass of the gonad with the total mass of the animal (King, 1995). This work aimed to determine of spawning season, sex ratio, length at first maturity and fecundity to develop fish production in the Bardawil lagoon.

\section{MATERIAL AND METHODS}

The study area was Bardawil lagoon (Fig.1). The lagoon is located in north Sinai Peninsula, bordered northerly by the Mediterranean Sea and southerly by Sinai desert. It is approximately $90 \mathrm{~km}$ long and 
$22 \mathrm{~km}$ across its widest point, and covers area of approximately $595 \mathrm{~km}^{2}$.

The lagoon is extremely shallow and the water level never exceeds three meters in depth.

A total of 573 specimens (rabbit fish, Siganus rivulatus) were collected at random from the early mixed catch of trammel net and shrimp bottom trawling catches in the Bardawil lagoon. Total length was measured to the nearest $\mathrm{mm}$, for total weight to the nearest $0.1 \mathrm{~g}$ and the weighing of gonads, scale $0.001 \mathrm{~g}$ sensitivity was used.



Fig. (1): Bardawil lagoon, showing the Bughaz1 and Bughaz2.

After the gonads had extracted, the specimens were sexed with naked eye. In order to determine the spawning season, individual gonads were taken. By the naked eye and by microscope in young specimens, mature individuals were determined. The gonads after being removed were weighed monthly; the gonad somatic indices (GSI) were calculated by equation of Bariche et al., 2003 as follows:

\section{GSI= (Gonad Weight) (Body Weight - Gonad Weight))*100}

Monthly, sex ratio for different length groups was calculated. During the spawning season, the length at first maturity $\left(\mathrm{L}_{\mathrm{m}}\right)$ was determined by examination of 163 gonads to determine the sex and the stage of maturity, where $50 \%$ of fish reach their sexual maturity was estimated by fitting the maturation curve between the percentage maturities of fish corresponding to each length class interval. Then $\mathrm{L}_{m}$ was estimated as the point on the $\mathrm{X}$-axis corresponding to $50 \%$ point on the $\mathrm{Y}$-axis.

The absolute fecundity $\left(\mathrm{F}_{\mathrm{abs}}\right)$ was defined as the number of mature eggs in the ovaries during the spawning season. 34 mature ovaries of adult females were used for length range from 14.5 to 21.6 $\mathrm{cm}$ total length.

The gonads were removed, weighed to the nearest $0.001 \mathrm{~g}$ and placed in glass bottle with $10 \%$ formalin. Later, the gonads were washed and dried. Subsamples were taken from the front, middle and rear sections of the ovaries. The ovarian tissue was removed and weighted to obtain the net eggs weight.

The Subsamples weighted, and eggs were well mixed, and placed on slide which was divided into squares. The eggs of five squares under the microscope were counted. The mean number, the total number of eggs in the subsample were counted. 
SINAI Journal of Applied Sciences (ISSN: 2314-6079), Vol.:(3), Is.:(3), Dec. 2014

Then, the absolute fecundity was calculated as:

$F_{a b s}=(($ Gonad Weight $*$ Egg Number in the Subsample) / Subsample Weight) (Yeldan and Avsar, 2000).

The relative fecundity $\left(\mathrm{F}_{\text {rel }}\right)$ was calculated as: $F_{r e l}=F_{a b s} /($ B.L or B.W.)

The relationship between the total length $\left(L_{T}\right)$ and fecundity can be described by the formula: $\quad F=a L^{b}$ Where: $\mathrm{F}$ is fecundity, $\mathrm{L}$ is total fish length $(\mathrm{cm})$ and a $\& b$ are constant whose values are determined by using the least squares method.

\section{RESULTES AND DISSCUTION}

\section{Spawning season and gonadosomatic index}

Figure (2) shows the monthly variation of the Gonado somatic index values, the lower values were recorded in April, October and November, the higher values were recorded in June, July and August with a peak in June where spawning season. These results agree with that resulted by Popper and Gundermann, 1975, Golani, 1990, Moharram, 1994, El-Okda, 1998 and EL-Far, 2008, as the spawning season of $S$. rivulatus from May to August in the Mediterranean Sea regions, while slightly differ with Yeldan and Avsar, (2002) from April to August (Turkey), for the same species.

The present results disagree with resulted by Popper et al., 1973 and Hashem, 1983 (March to April) and Amin, 1985 (from February to April) of the Red Sea, where they decided that, the spawning season of $S$. rivulatus in Red Sea begins earlier than in Mediterranean.

\section{Sex ratio}

Figure 3 showed that, a total of $538 \mathrm{~S}$. rivulatus, in Bardawil lagoon, dividing to 255 females and 283 males, as female to male sex ratio was $1: 1$ around the year with slightly change of ratio month by month between females to males. The fluctuation in the sex ratio from May to August (spawning season) in Bardawill lagoon, may be due to spawning and feeding migrations between open Mediterranean Sea for spawning and the lagoon for feeding as many species (Sparus aurata, Mugil cephalus and Solea solea). Yeldan and Avsar, 2000 mentioned that, the fluctuation in the sex ratio of females to males due to spawning and feeding migrations.

The seasonal variations in the sex ratio may possibly be due to the difference in the length or age at sexual maturity and the difference in length distribution in relation to depth (Ismen, 2006).

\section{Length at first maturity $\left(L_{m}\right)$}

The length at first maturity was estimated at $13.8 \mathrm{~cm}$ and $14.4 \mathrm{~cm}$ for female and male respectively (Fig. 4).

The size at sexual maturity of fish may be important to assess the optimum size of first capture of a species. Our result was slightly lower to that of Hashem, 1983 (Res Sea), and El-Far, 2008 (Mediterranean Sea), they resulted that, sexually maturity of $S$. rivulatus is attained at about 14-16 cm (from age II on wards) and $14.2 \mathrm{~cm} \mathrm{(1.882} \mathrm{year)} \mathrm{for}$ males, $13.9 \mathrm{~cm}$ (1.992 year) for females respectively.

Tharwat, 2004, found that, the length at first sexual maturity $\left(L_{m}\right)$ of $S$. canaliculatus at $18 \mathrm{~cm}$ and $19 \mathrm{~cm}$ for males and females, respectively. Also, he resulted that, the fishes larger than $22 \mathrm{~cm}$ total length of both sexes were fully mature.

The slightly lower may be related to unsuitable environment where the salinity was higher in the lagoon.

Duray, 1998, mentioned that, Sexual maturity is attained in less than a year but at different sizes in various species. 


\section{Fecundity}

The relation between body size (total length and body weight) and fecundity (absolute and relative) of $S$. rivulatus were calculated. The number of eggs gradually increased with the increasing of fish length and weight as fish of $14.4 \mathrm{~cm}(41.5$ g.) to lay eggs about 57244 reaching maximum of about 356410 eggs for a fish of $21.6 \mathrm{~cm}(149 \mathrm{~g}$.).
The relative fecundity gradually increased from 1228 to 2392 eggs per gm with average of $1798 \mathrm{~g}^{-1}$. The relation between fecundity and size was illustrated in Fig. (5 and 6).In this study, the fecundity is lower compared with the previous studied for the same species in different regions as Alexandria coast, were found that the relative fecundity reached to 4230 eggs per gm (El-Far,

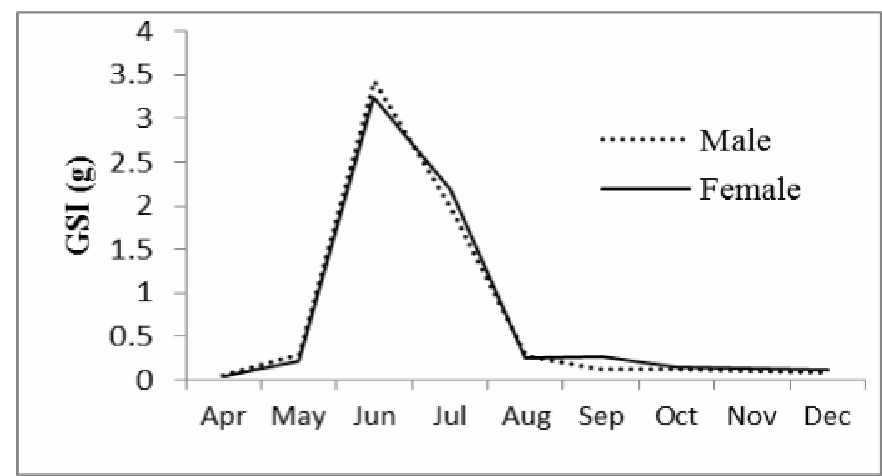

Fig. (2): Monthly variation of gonad somatic index (GSI) of male and female of Siganus rivulatus in Bardawil lagoon during the fishing season of 2012.

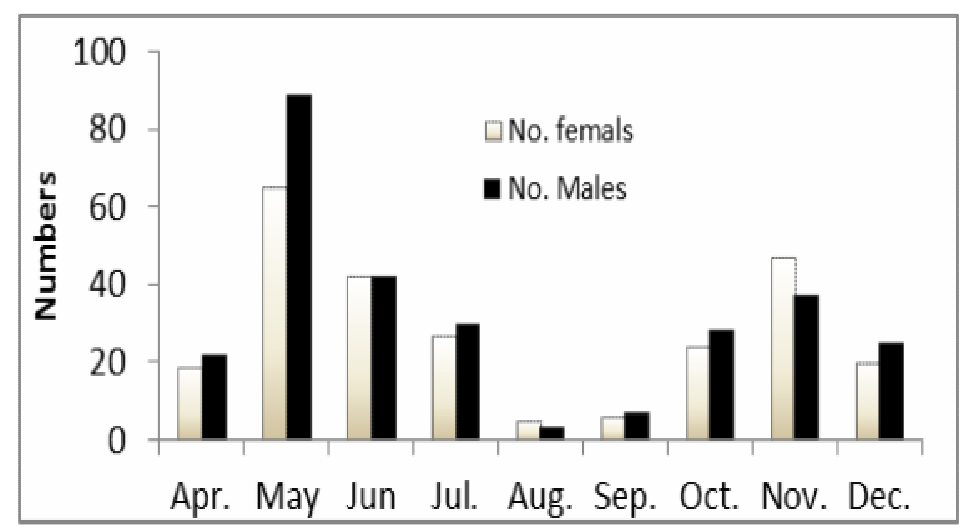

Fig. (3): Monthly variation of male and female number (Sex ratio) of $S$. rivulatus in Bardawil lagoon during the fishing season of 2012.
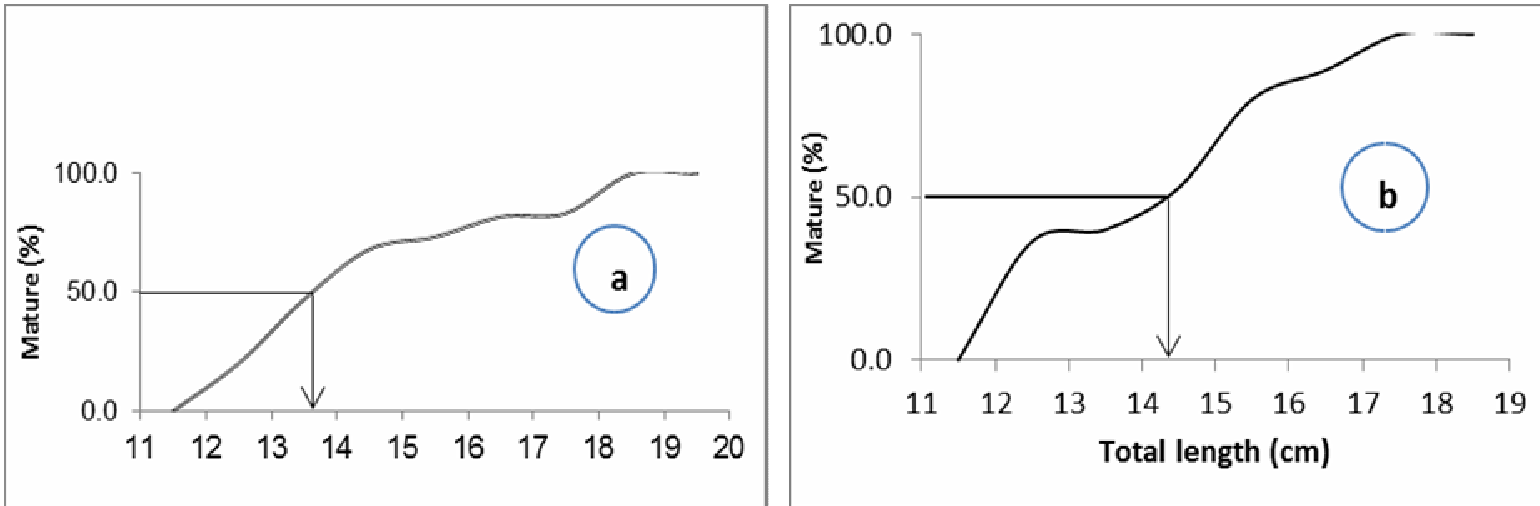

Fig. (4): Length at first maturity of female (a) and male (b) of $S$. rivulatus in Bardawil lagoon during the fishing season of 2012 . 
SINAI Journal of Applied Sciences (ISSN: 2314-6079), Vol.:(3), Is.:(3), Dec. 2014

2008) and average $F_{\text {rel }}=2123$ eggs per gm of $S$. rivulatus in The Eastern Mediterranean Sea, Lebanon coast (Bariche et al., 2003).

The absolute fecundity was increased with a total length and described by power equation $F=a L^{b}$ as $\mathrm{F}=0.2629$ $\mathrm{L}^{4.6005}$.Values of the constants ( $\mathrm{a}$ and $\mathrm{b}$ ) may vary according to the studied population and to environmental variations (Kartas and Quignard, 1984) also, they recorded that the fish condition, varies with region or year.

\section{CONCLUSION}

The current study recommends the following:

1. Prevent fishing craft Shrimp (Al kalssa) in the months of June to July, where spawning season of $S$. rivulatus in the Bardawil lagoon.

2. Adjusted net triangular opening in line with the size of the fish caught (at least $14 \mathrm{~cm}$ ), a height at the beginning of sexual maturity

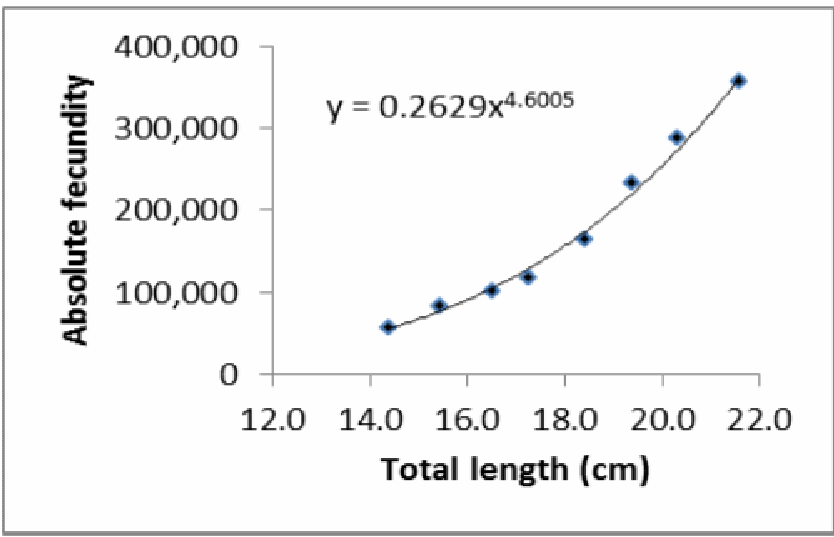

Fig. (5): Relationship between total length and Absolute fecundity of $S$. rivulatus in Bardawil lagoon during the fishing season of 2012.

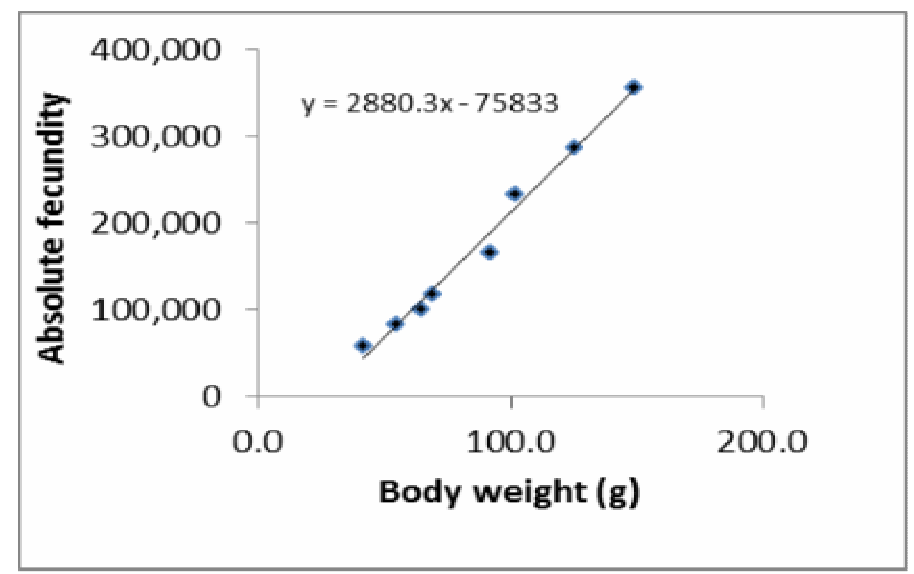

Fig. (6): Relationship between body weight (g) and Absolute fecundity of Siganus rivulatus in Bardawil lagoon during the fishing season of 2012. 


\section{REFFERENCES}

Amin, E. M., (1985). Seasonal development changes in the ovaries of Siganus rivulatus, Forsskal, from the Red Sea. Bull. Inst. Oceanogr. Fish. A.R.E., 11: 131-147.

Bariche, M., M. H. Vivien, J. P. Quignard, (2003). Reproductive cycles and spawning periods of two Lessepsian Siganid fishes on the Lebanese coast. Journal of Fish Biology 62: 129-142.

Bariche, M., R. Sadek and E. Azzurro, (2009). Fecundity and condition of successful invaders: Siganus revulatus and $S$. luidus (Actinopterygii: Perciformes: Siganidae) in the eastern Mediterranean Sea. Acta. Ichthyologica Etpiscatoria, 39(1):1118.

Cailliet, G. M., M. S. Love and A. W. Ebeling, (1996). Fishes, A field and laboratory manual on their structure, Identification, and natural history. Wadsworth Publishing Company. Belmont, California.

Duray, M. N., (1998). Biology and Culture of Siganids. Seafdec, Book, $54 p$ http://repository.seafdec.org.ph

EL-Far, A. M. M., (2008). Artisanal fishery off Alexandria costal area with special reference to the fishery biology of Siganus Spp . M.Sc. Thesis faculty of Science Zagazig University.

El-Okda, N. I.,(1998). Comparative studies on certain biological aspects of Siganus in marine waters of Egypt. $\mathrm{Ph}$. D. Thesis, Fac. Sci., (Benha) Zagazig. Univ.

Galil, B.S., (2007). Loss or gain Invasive aliens and biodiversity in the Mediterranean Sea. Marine Pollution Bulletin. 55: 314-322.
Golani, D., (1990). Environmentallyinduced meristic changes in Lessepsian fish migrants, a comparison of source and colonizing populations, Bulletin de 1'Ist. Ocean., Monaco, n. Special 7: 143-150.

Golani, D., L. Orsi-Relini, E., Massuti, J.-P. Quignard, (2002). CIESM Atlas of Exotic Species in the Mediterranean. CIESM Publishers, Vol. 1. Fishes. Monaco.

Golani, D., L. Orsi-Relini, E., Massuti, J.-P. Quignard,( 2004). Dynamics of fish invasions in the Mediterranean: update of the CIESM fish atlas. Rapport de la Commission International pours l'Exploration Scientifique de la Mer Méditerranée37:367.

Hashem, M.T., (1983). Biological studies on Siganus rivulatus (Forsskal, 1775) in the Red Sea. J.Fac. Mar.Sci. 3:119-128.

Ismen, A., 2006. Growth and reproduction of Por goat fish (Upeneus Pori Ben-Tuvia and Golani, 1989) in Uskenderuns Bay, the Eastern Mediterranean .Turk.J.Zool., 30:91-98.

Kartas, F. and J. P. Quignard (1984). La fécondité des poisons téléostéens. Collection de Biologie des Milieux Marins 5. Masson, Paris.

King, M., (1995). Fisheries biology, Assessment and Management Fishing News Books, Australia, 341pp.

Moharram, S. G., (1994). Reproductive biology and induced spawning of one species of family Siganidae. $P h$. D. Thesis, Fac. Sci. Suez Canal Univ. $235 p$.

Popper, D., and N. Gundermann, (1975). Some ecological and behavioral aspects of siganid populations in the Red Sea and Mediterranean coasts of Israel in 
SINAI Journal of Applied Sciences (ISSN: 2314-6079), Vol.:(3), Is.:(3), Dec. 2014

relation to their suitability for aquaculture. Aquaculture, 6:127-141.

Popper, D., H. Gordin, and G. W.

Kissil, (1973). Fertilization and

hatching of rabbitfish Siganus

rivulatus. Aquaculture, 2(1): 37-44.

Tharwat, A.A., (2004). Reproductive cycle and mariculture potential of the rabbitfish Siganus canaliculatus in
Saudi Arabia. Egypt. J. Aquat. Biol. \& Fish., (in publication).

Yeldan, H. and D. Avsar, (2000). A Preliminary study on the Reproduction of the Rabitfish, Siganus rivulatus (Forsskål, 1775) in the northeastern Mediterranean. Turk. J. of Zool. 24: 173-182.

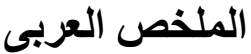

دراسة أولية عن تكاثر أسماك السيجان ببحيرة البردويل بشمال سيناء ـ مصر

سماح على مقبل، جابر دسوقى إبراهيم حسنين، محمد سالم أحمد عبد الله

قسم الثروة السمكية والأحياء المائية، كلية العلوم الزر اعية البيئية بالعريش، جامعة قناة السويس، شمال سيناء، مصر

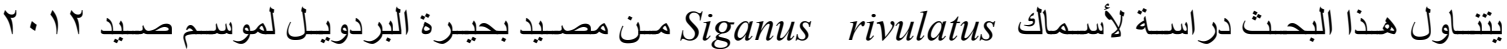

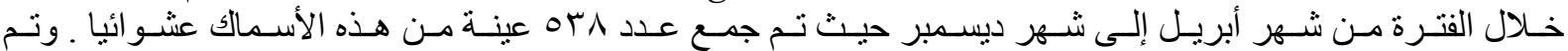

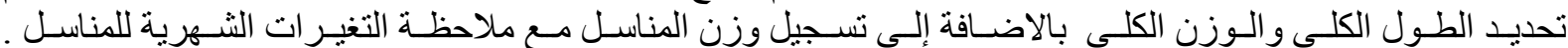



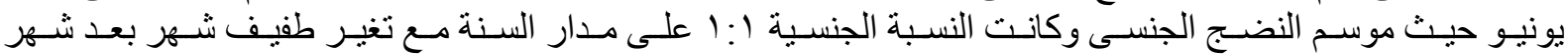

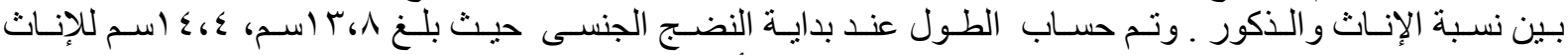

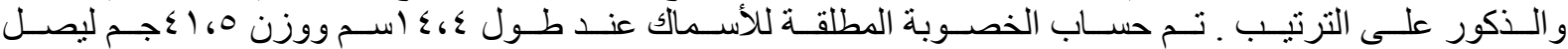

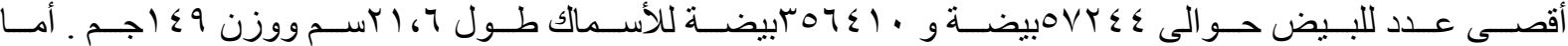

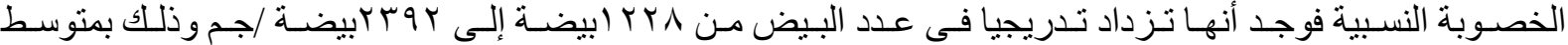

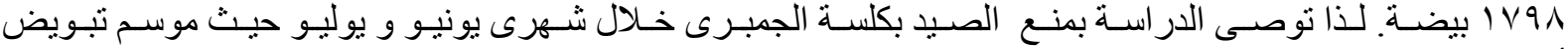
أسماك السيجان فى بحيرة البردويل. لـان. الكلمات الاسترشادية: بحيرة البردويل، أسماك السيجان، النضج الجنسى. 
Mekbel, et al. 